\title{
Effect of meteorological parameters on incidence of brown leaf spot in rice crop under different planting methods
}

\section{L.K. DHALIWAL, SARABJOT KAUR SANDHU, SUKHJEET KAUR and SUKHVIR SINGH}

\author{
School of Climate Change and Agricultural Meteorology \\ Punjab Agricultural University, Ludhiana \\ Email: dhaliwal1969@pau.edu
}

\begin{abstract}
The field experiments were conducted during three kharif seasons 2012, 2013 and 2014 to study the effect of meteorological parameters on brown leaf spot of rice under different transplanting dates, methods and plant population. The experiment was laid out in split-split plot design with two transplanting dates $\left(15^{\text {th }}\right.$ June and $30^{\text {th }}$ June) in main plots, three methods of planting (conventional, SRI and furrow) in sub plots and two plant population (625 and 300 plants per $\mathrm{m}^{2}$ ) in sub-sub plots with three replications. The brown leaf spot incidence was recorded at weekly interval from the start of its incidence. The incidence of disease (percentage) was higher under conventional planting (58.6\%) followed by SRI (52.3 \%) than furrow planting $(49.9 \%)$. The disease incidence was 5 per cent higher in high plant population (625 plants $\mathrm{m}^{-2}$ ) as compared to lower plant population (300 plants $\mathrm{m}^{-2}$ ) mainly due 4.1 per cent higher relative humidity within canopy. The correlation analysis revealed that minimum temperature and evening relative humidity significantly affected the disease incidence. The regression model developed with 2012 and 2013 data had highly significant $R^{2}$ values which was validated with 2014 data.
\end{abstract}

Key words: Brown spot incidence, conventional planting, system of rice intensification (SRI), furrow planting, microclimate

Rice production is influenced by weather variables which also play important role in the appearance, multiplication and spread of the pests and diseases. Samui. et al. (2004) correlated different pests of rice in Kerala with weather parameters and developed forewarning models. Sheath blight disease in rice was correlated with weather parameters by Rini Pal et al. (2017), while Yella Reddy et al. (2006) developed dynamic weather based indices for forewarning rice blast in A.P. and H.P.

The brown leaf spot is a chronic disease of rice crop which causes yield losses in relative terms from 4 to 52 per cent. Recently brown leaf spot of rice has increased in both, its incidence and severity on certain varieties of rice and has become wide spread throughout Punjab (Pannu et al. 2002; Lore and Raina 2003). To cope with the changing climatic conditions and their impact on rice diseases, there is a need to adopt better management practices viz. selection of planting method and plant population. The knowledge on interaction of weather, planting methods, plant population and diseases can be helpful in management of brown leaf spot of rice. Keeping this in view, the experiments were conducted to study the effect of different planting methods and meteorological parameters on incidence of brown leaf spot of rice.

\section{MATERIALS AND METHODS}

Field experiments were conducted during three kharif seasons (2012, 2013 and 2014) at the Research Farm, School of Climate Change and Agricultural Meteorology, Punjab Agricultural University, Ludhiana. The area experiences an average annual rainfall of $732 \mathrm{~mm}$ of which about 80 per cent is received during June to September. The experiment was laid out in split-split plot design with dates of transplanting $\left(\mathrm{D}_{1}\right.$ and $\left.\mathrm{D}_{2}\right)$ in main plots and three planting methods viz. conventional $\left(\mathrm{M}_{1}\right)$, System of rice intensification (SRI) $\left(\mathrm{M}_{2}\right)$ and furrow planting $\left(\mathrm{M}_{3}\right)$ in sub plots and two plant populations $\mathrm{P}_{1}\left(625\right.$ plants $\left.\mathrm{m}^{-2}\right)$ and $\mathrm{P}_{2}(300$ plants $\left.\mathrm{m}^{-2}\right)$ in sub-sub plots and was replicated four times. Data on disease incidence was recorded at weekly interval from the initiation of disease till the maturity of the crop.

The disease incidence was observed from 20 randomly selected plants from each plot at weekly interval. Disease incidence was calculated by using the following formula (Teng and James 2002).

Disease Incidence $(\%)=\frac{\text { Number of diseased plants }}{} \times 100$ Total number of plants examined 
Table 1: Comparison of brown leaf spot incidence (\%) and micrometeorological parameters within crop canopy under different treatments (Pooled analysis)

\begin{tabular}{|c|c|c|c|}
\hline Treatment & Disease incidence DI (\%) & Canopy temperature $\left({ }^{\circ} \mathrm{C}\right)$ & Relative humidity (\%) \\
\hline \multicolumn{4}{|c|}{ Date of transplanting } \\
\hline $15^{\text {th }}$ June & 52.4 & 28.3 & 76 \\
\hline $30^{\text {th }}$ June & 56.4 & 27.2 & 78 \\
\hline P-value & 0.01 & - & - \\
\hline \multicolumn{4}{|l|}{ Planting methods } \\
\hline Conventional & 58.6 & 28.0 & 80 \\
\hline SRI & 52.3 & 29.4 & 77 \\
\hline Furrow & 49.9 & 30.5 & 75 \\
\hline P-value & 0.03 & - & - \\
\hline \multicolumn{4}{|l|}{ Plant population } \\
\hline 625 plants per $\mathrm{m}^{2}$ & 56.8 & 27.0 & 82 \\
\hline 300 plants per $\mathrm{m}^{2}$ & 51.5 & 28.5 & 78 \\
\hline P-value & 0.003 & - & - \\
\hline
\end{tabular}

Multi-treatment comparison using Tukey method $(\mathrm{P}<0.05)$ indicates significant values.

Table 2: Correlation coefficients between disease incidence and meteorological parameters under different planting methods (Pooled analysis)

\begin{tabular}{lcccccc}
\hline Treatments & Tmax & Tmin & RHm & RHe & RF & SSH \\
\hline Conventional & -0.35 & $-0.81^{* *}$ & 0.36 & $-0.72^{* *}$ & -0.35 & 0.21 \\
& $(0.16)$ & $(<0.0001)$ & $(0.14)$ & $(0.0007)$ & $(0.15)$ & $(0.39)$ \\
SRI & -0.37 & $-0.82^{* *}$ & 0.37 & $-0.71^{* *}$ & -0.31 & 0.23 \\
& $(0.13)$ & $(<0.0001)$ & $(0.13)$ & $(0.0009)$ & $(0.15)$ & $(0.35)$ \\
Furrow & -0.40 & $-0.83^{* *}$ & 0.33 & $-0.73^{* *}$ & -0.36 & 0.19 \\
& $(0.10)$ & $(<0.0001)$ & $(0.12)$ & $(0.0007)$ & $(0.14)$ & $(0.45)$ \\
\hline
\end{tabular}

Parenthesis value indicates $\mathrm{P} \leq 0.05$ and $\mathrm{P} \leq 0.01$

Where, Tmax: Maximum temperature, Tmin: Minimum temperature; RHm: Morning relative humidity; RHe: Evening relative humidity; RF: Rainfall; SSh: Sunshine hours;

\section{Analysis of data}

The disease incidence data w.r.t meteorological parameters and microclimatic parameters was pooled and analysed using statistical software SAS 9.3 (Statistical Analysis Software) (SAS 1990). Effect of meteorological parameters viz. weeklymaximum temperature $\left(\mathrm{T}_{\max }\right)$, minimum temperature $\left(\mathrm{T}_{\text {min }}\right)$, morning relative humidity $\left(\mathrm{RH}_{\mathrm{m}}\right)$, evening relative humidity $\left(\mathrm{RH}_{\mathrm{e}}\right)$, sunshine hours ( $\left.\mathrm{SSH}\right)$ and weekly total rainfall (RF) on disease incidence was determined by correlation analysis. Disease predictive model for brown leaf spot was developed based on two years (2012 \& 2013) pooled disease incidence data and meteorological parameters using regression analysis. Regression models developed for different planting methods were validated for 2014 .

\section{RESULTS AND DISCUSSION}

\section{Growing environment and disease incidence}

The per cent brown leaf spot incidence and corresponding weather parameters viz. canopy temperature and relative humidity are presented in Table 1 . The results of experiments indicated that the brown leaf spot incidence was 4 per cent higher under $30^{\text {th }}$ June transplanted crop as compared to $15^{\text {th }}$ June transplanted crop because of favourable microclimatic conditions. During second date of sowing the canopy temperature was lower whereas relative humidity within canopy was higher as compared to first date of sowing.

The incidence of disease was highest under 


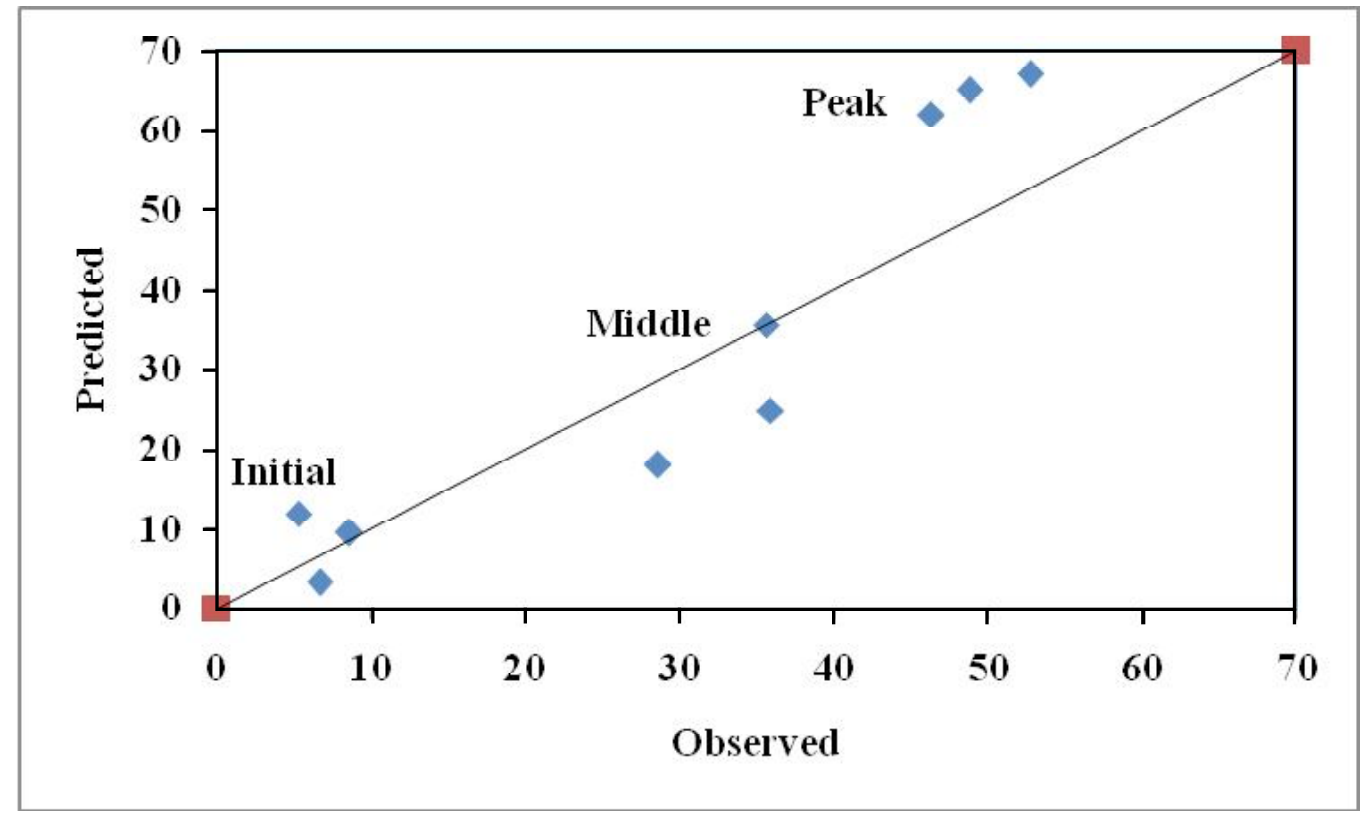

Fig. 1: Comparison of observed and predicted brown leaf spot disease incidence at different disease levels

Table 3: Regression analysis between meteorological parameters and different planting methods (Pooled analysis)

\begin{tabular}{llll}
\hline Methods & Equation & $\mathrm{R}^{2}$ & P value \\
\hline Conventional & $\mathrm{Y}=309.19-7.69 \mathrm{Tmax}+1.22 \mathrm{Tmin}+0.35 \mathrm{RHm}-1.44 \mathrm{RHe}-0.02 \mathrm{RF}-0.37 \mathrm{SSh}$ & $0.77^{*}$ & 0.005 \\
SRI & $\mathrm{Y}=293.10-7.29 \mathrm{Tmax}+1.46 \mathrm{Tmin}+0.36 \mathrm{RHm}-1.29 \mathrm{RHe}-0.01 \mathrm{RF}-0.29 \mathrm{SSh}$ & $0.76^{*}$ & 0.004 \\
Furrow & $\mathrm{Y}=316.93-7.94 \mathrm{Tmax}+1.36 \mathrm{Tmin}+0.24 \mathrm{RHm}-1.38 \mathrm{RHe}-0.01 \mathrm{RF}-0.46 \mathrm{SSh}$ & $0.82^{*}$ & 0.001 \\
\hline
\end{tabular}

Where, $\mathrm{Y}=$ Brown leaf spot per cent incidence

conventional planting (58.6\%) followed by SRI (52.3\%) and furrow planting $(49.9 \%)$. Microclimate within the crop was modified under furrow and SRI methods which further influenced the disease incidence. The percent disease incidence was 5 per cent higher in higher plant population (625 plants $\left.\mathrm{m}^{-2}\right)$ as compared to lower plant population (300 plants $\mathrm{m}^{-2}$ ) due to dense crop canopy having higher humidity which ultimately resulted in higher incidence of brown leaf spot. Hegde et al. (2000) reported that brown leaf spot incidence was influenced by planting methods. Disease incidence was low in row seeding using a drum seeder and line transplanting using a transplanter compared to broadcasting of pre-germinated seeds. Pannu et al (2005) also reported that prevailing weather conditions during crop season significantly affected the brown leaf spot incidence.

\section{Effect of meteorological parameters and disease incidence}

The disease development was positively correlated with morning relative humidity and negatively correlated with evening relative humidity under different planting methods (Table 2). Generally, development is faster in the presence of higher relative humidity within the crop canopy. There was a significant strong relationship of evening relative humidity with disease development. The incidence of brown leaf spot had non significant relationship with rainfall and sunshine hours.

\section{Regression analysis}

Regression analysis carried out between brown leaf spot incidence and different meteorological parameters revealed significant $\mathrm{R}^{2}$ values under different planting methods (Table 3). Higher $\mathrm{R}^{2}$ values indicated that different meteorological parameters were responsible for disease variability in rice. Pannu et al (2005) also reported that brown leaf spot of rice was significantly influenced by different meteorological parameters.

Three models developed using data of 2012 and 2013 were validated for 2014 (Fig.1). The models showed 1-10 percent variability between observed and predicted disease incidence values. Hence these models can be used to predict the brown spot disease incidence in rice. 


\section{CONCLUSIONS}

The development of brown leaf spot is influenced by temperature, relative humidity and amount of rainfall during the crop season. Furrow planting can serve as suitable disease management practices. Regression model developed can be used for forewarning of brown spot of rice in region.

\section{ACKNOWLEGMENT}

The financial aid provided by University grant commission (UGC) under the adhoc research project entitled "Microclimate and disease interaction under different water saving techniques in Rice" is acknowledged.

\section{REFERENCES}

Hegde, Y.R., Ganajaxi and Angadi, V.V.(2000). Effect of method of planting on the incidence of brown spot of rice. $A d v$. Agric. Res. 14: 167-168.

Lore, J. S. and Raina, G. L. (2003). Status of brown spot of rice in Punjab. Progressive Farming., pp. 20.
Pannu, P. P. S., Chahal, S. S., Kaur, M. and Sidhu, S. S. (2005). Influence of weather variables on the development of brown leaf spot caused by Helminthosporium oryzae in rice. Indian Phytopath., 58: 489-496.

Rini Pal, Mandal, D., Biswas, M.K. and Panja, B.N. (2017). Effect of weather parameters on initiation and progression of sheath blight of rice. J. Agrometeorol., 19(1):39-43.

Samui, R.P., Chattopadhyay, N., Sabale, J.P. and Balchandran, P.V. (2004). Weather based forewarning models for major pests of rice in Pattambi region (Kerala). $J$. Agrometeorol., 6 (Special issue):105-114.

Teng, P. S. and James, W. C. (2002). Disease and yield loss assessment. Monsanto Company Makati city, Philippines and ISAAA ameri center, Cornell University, USA.

Yella Reddy, D. Prabhakar, M., Ramakrishna, Y.S., Reddy, C.S., Prasad, Y.G. and Nagalakshmi, T. (2006). Dynamic cumulative weather based index for forewarning of rice blast. J. Agrometeorol., 8(1):1-6. 